FACTA UNIVERSITATIS

Series: Working and Living Environmental Protection Vol. 18, No 1, 2021, pp. 1 - 9

https://doi.org/10.22190/FUWLEP2101001N

Original Scientific Paper

\title{
GEOTHERMAL ENERGY RESOURCE POTENTIAL IN NIGERIA FROM AEROMAGNETIC REVIEWS: ANOTHER PANACEA FOR ENERGY CRISES AND ENVIRONMENTAL GLOBAL WARMING
}

\author{
UDC 620.91:550.36(669)
}

\author{
Levi I. Nwankwo \\ Earth and Environment Research Unit, Department of Physics, \\ Federal University of Kashere, Gombe State, Nigeria
}

\begin{abstract}
An effort has been made in this paper to advocate a panacea to the prevailing energy crisis in Nigeria by reviewing the country's geothermal energy resource potential from regional aeromagnetic calculations. There is widespread occurrence of warm/hot springs in Nigeria, which gives credence to the availability and abundance of geothermal reserves. Results of aeromagnetic investigations also confirm that areas with anomalous high heat flow exist in Nigeria, showing high prospects of employing geothermal energy for direct and indirect energy applications. It is, therefore, imperative for Nigeria to take a quantum leap in holistic renewable energy research and development through appropriate government science advice, policy and environmental management.
\end{abstract}

Key words: geothermal energy, renewable energy, environmental policy, warm springs, Nigeria

\section{INTRODUCTION}

The increasing demand and cost of electricity in the past three decades have accelerated the search all over the world for and the development of renewable energy sources; namely solar, bio-mass, wind, hydro, geothermal, among others. The energy sector is of strategic importance to the economy of any nation, and a major driver for growth. The sector has a major role to play in reducing poverty, improving productivity and enhancing the general quality of life [1]. However, Nigeria is currently facing an energy crisis, with less than $47 \%$ of the population having access to electricity. At the moment, Nigeria is only able to generate about 4,000 MW of power (out of an estimated

Received December 31, 2019 / Accepted April 29, 2021

Corresponding author: Levi Ikechukwu Nwankwo

Federal University Kashere, P.M.B. 0182 Gombe, Gombe State, Nigeria

E-mail: levinwankwo@yahoo.com 
potential of $12,500 \mathrm{MW}$ ) [2], which is paltry and grossly inadequate for a population of about 200 million people, by this means necessitating nationwide load-shedding for rationing electricity [3]; whereas South Africa with a population of only 60 million generates over 50,000 MW [4]. It is estimated that for a significant economic growth rate of $10 \%$ to be achieved in Nigeria, about $30,000 \mathrm{MW}$ of power will be required by 2020 and 78,000 MW by 2030 [3]. Now that we are just a few weeks away from 2020, the generation of an additional 26,000 MW of power may therefore not be feasible today. Nevertheless, there is still a need for a broadened energy mix for electricity supply from the present conventional sources to renewable sources. On the $25^{\text {th }}$ January 2015 , while receiving the visiting President of the United States of America, the Indian Prime Minister announced that adequate arrangements had been made in India to generate a whopping additional 100,000 MW by 2020 from diverse renewable energy options. This is in line with one of the Sustainable Development Goals (\#7) of the United Nations (UN) that is to ensure access to affordable, reliable, sustainable and modern energy for all. The UN projected that by 2030, there should be a substantial increase in the share of renewable energy in the global energy mix, including the facilitation of renewable energy research and technology, especially in developing and least-developed countries. As a result, Nigeria has no option than to untiringly strive to increase its electricity generation capacity through strong policies that would promote holistic development and utilization of renewable energies in Nigeria.

Another substantial reason for renewable energy promotion is environmental concerns. More than $40 \%$ of global sources of $\mathrm{CO}_{2}$ emission are from fossil-based electricity generation and heating (Fig. 1) [5]. Of course, the percentage would be much more in Nigeria since almost every household and business establishment produces their electricity needs by means of domestic and industrial gasoline electricity generators. As a result of the unchecked emission of greenhouse gases, regional impacts of climate change prediction showed that by the year 2020, between 75 and 250 million people in Africa may likely be exposed to increased water stress; reduced yields from rain-fed agriculture, and severely compromised agricultural production, including access to food [4]. Accordingly, it is expected that acceptable measures and sustainable policies be formulated by national governments and regional bodies to mitigate these impacts. One of such strategies should be in renewable energy production.

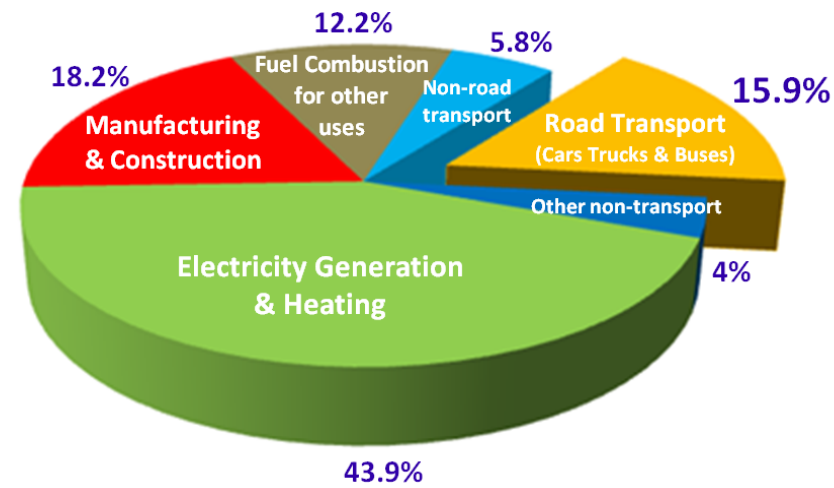

Fig. 1 Global Sources of $\mathrm{CO}_{2}$ Emission (www.oica.net) 
In this paper, an attempt has been made to contribute and proffer solution to the prevailing energy crisis in Nigeria, by means of geomagnetic evaluation of geothermal energy resources in Nigeria. It is expected that the outcome would bridge the gap between scientists and policy makers and also become an additional panacea for energy crises and global warming in Nigeria.

\section{GEOTHERMAL ENERGY}

Geothermal energy is the natural heat from Earth's subsurface, which is created as a result of the cooling of the Earth since its early history, and the decay of long-lived radioactive isotopes. The latter is the main source (about 80\%) of Earth's internal heat which powers all geodynamic processes [6]. The heat is produced in the form of a thermal reservoir when rising hot water and steam in the subsurface are trapped in permeable and porous rocks under a layer of impermeable rock. This energy provides a clean resource that can be used to generate electricity, heat buildings and baths, and grow plants in greenhouses (Fig. 2) [7]. Exploration and exploitation of geothermal heat also provide opportunities to increase energy options, energy market flexibility, and decrease greenhouse gases [8].

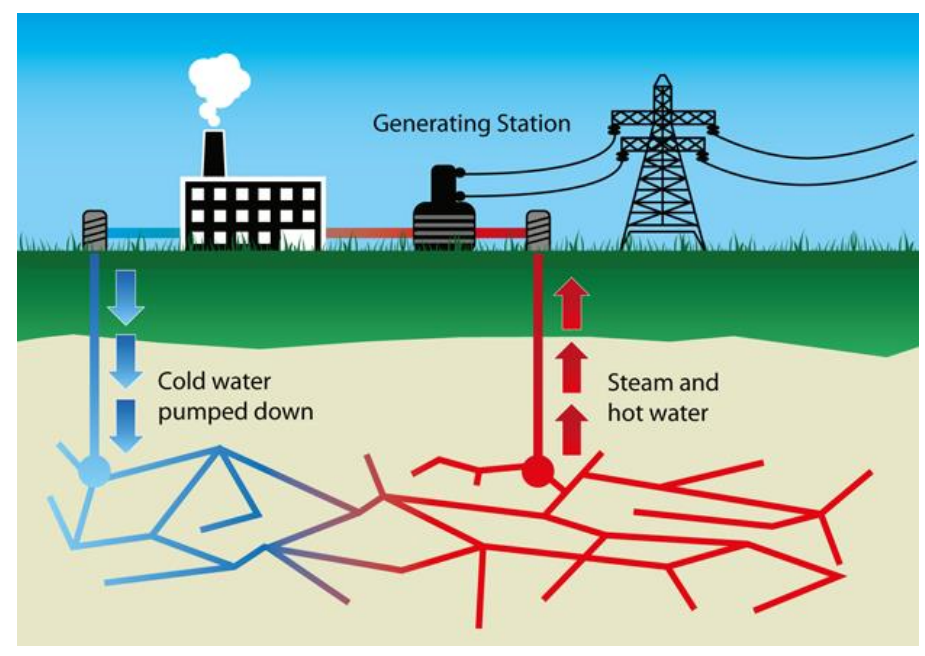

Fig. 2 Geothermal Formations (wikipedia.org)

Globally, geothermal energy has been established as a sustainable, renewable, environmentally sound, and economically competitive contributor to energy supply [9]. As such, geothermal energy has attracted increasing attention as an effective addition to the national grids of countries, even in Africa (Table 1) [10]. Energy use in Africa is the lowest in the world and also has the least developed structure. The continent has about $15 \%$ of the world's population but its share of electricity use is less than $5 \%$ of the world. Only about $25 \%$ of the African population has access to electricity. More than half of the current energy use is traditional bio-mass that causes health problems and deforestation. 
Table 1 Installed geothermal electricity capacity (after [10])

\begin{tabular}{lccc}
\hline Country & Capacity (MW) & Capacity (MW) & Capacity (GW) \\
& 2007 & 2010 & $2015^{*}$ \\
\hline Iceland & 421.2 & 575 & 0.7 \\
Philippines & 1969.7 & 1904 & 1.9 \\
El Salvador & 204.2 & 204 & \\
Costa Rica & 162.5 & 166 & 0.6 \\
Kenya & 128.8 & 167 & 1 \\
New Zealand & 471.6 & 628 & 1.4 \\
Nicaragua & 87.4 & 88 & 1.1 \\
Indonesia & 992 & 1197 & 0.9 \\
Mexico & 953 & 958 & 3.6 \\
Italy & 810.5 & 843 & 0.5 \\
United States & 2687 & 3086 & 0.6 \\
Japan & 535.2 & 536 & \\
Iran & 250 & 250 & \\
Turkey & 38 & 82 & \\
Russia & 79 & 82 & \\
Papua-New Guinea & 56 & 56 & \\
Guatemala & 53 & 52 & \\
Portugal & 23 & 29 & \\
China & 27.8 & 24 & \\
France & 14.7 & 16 & \\
Ethiopia & 7.3 & 7.3 & \\
Germany & 8.4 & 6.6 & \\
Austria & 1.1 & 1.4 & \\
Australia & 0.2 & 1.1 & \\
Thailand & 0.3 & 0.3 & \\
\hline Total & 981.9 & & \\
\hline www.statista.com/statistics/270251/installed-geothermal-energy-capacity-by-country/ & \\
& & & \\
\hline
\end{tabular}

Although, Africa is endowed with abundant energy resources such as hydropower, geothermal, wind and solar, only less than $10 \%$ and $1 \%$ of the continent's hydroelectric and geothermal power generation potentials have been developed to date, respectively [11]. For example, countries such as Kenya and Ethiopia have installed a capacity of about 217 MW from geothermal development, Djibouti, Eritrea, Tanzania, Uganda, Rwanda and Comoros are at various geothermal exploration stages. While other countries such as Burundi, the Democratic Republic of Congo, Malawi, Zambia, and Mozambique are presently conducting inventory work of geothermal resource potential in their domains [11].

\subsection{Physical Evidence of Geothermal Manifestations in Nigeria}

Widespread occurrence of physical (surface) geothermal manifestation exists in Nigeria, which gives credence to the availability and abundance of geothermal reserves. For example, Akiri town in Nasarawa State has a hot spring, with a measured surface temperature of about $53.5^{\circ} \mathrm{C}$, Ruwan Zafi located in Lamurde, Adamawa State has a hot spring with a temperature of $54{ }^{\circ} \mathrm{C}$ and Ikogosi warm spring in Ekiti State has a measured temperature of $71{ }^{\circ} \mathrm{C}$ at source [12]. Wikki warm spring also exists in Bauchi State.

Hot springs are indicators of probable high geothermal potential; therefore, it is evident that there could be traces of subsurface geothermal reservoirs in the subsurface that should be explored in Nigeria. 


\subsection{Application of Aeromagnetic Surveys in Geothermal Exploration}

It is necessary to conduct regional geophysical investigations to elucidate the subsurface geothermal reserves. Aeromagnetic (airborne magnetic) surveys are one of the many important parts of the complex of geophysical geothermal exploration methods. Generally, airborne surveys are preferred because they allow faster and usually cheaper coverage of large and inaccessible areas. The data obtained from such surveys are usually presented in form of maps which allows, in addition to quantitative interpretation, a visualization of the geological structures of the subsurface of the Earth [13].

Studies have shown that the depth to the bottom of magnetic sources (DBMS) in the crust can be estimated from the power spectrum of observed magnetic anomalies [14 21]. There are different mathematical models for such magnetic depth calculations. These include spectral-peak method [14], spectral-centroid method [15 - 18], scaling-spectral or power-law correction method [19], forward modelling of the spectral peak method [21] and modified-centroid fractal method [22], among others.

The derived DBMS is also considered as an index of the Curie-point depth (CPD) $[17,18,22]$. Crustal rocks lose their magnetization at the Curie-point temperature (CPT), which is a theoretical surface in the crust with a temperature of approximately $580{ }^{\circ} \mathrm{C}$. At CPT, ferromagnetic minerals lose their ferromagnetic properties. The thermal agitation causes the spontaneous alignment of the various domains to be destroyed/randomized so that the ferromagnetic minerals become paramagnetic $[23,24]$. Thus, the CPT isotherm corresponds to the basal surface of the magnetic crust. Consequently, the ability to estimate the DBMS is also an ability to evaluate the CPD, which can be translated into subsurface heat flow (HF) estimation using the relation [18]:

$$
H F=-\sigma\left(\frac{\theta_{c}}{Z_{b}}\right)
$$

where $\sigma, \theta_{c}$, and $Z_{b}$ are thermal conductivity, Curie-temperature and DBMS respectively. Thermal conductivity of $2.5 \mathrm{Wm}^{-1}{ }^{\circ} \mathrm{C}^{-1}$ as an average for igneous rocks and Curie-temperature of $580^{\circ} \mathrm{C}[25,26]$ are commonly used for Nigeria.

The primary observable quantity in geothermal exploration is the heat flow [27]. Although heat flow tends to be strongest along tectonic plate boundaries where volcanic activity transports high-temperature material to near the surface (Fig. 3), parts of the world far from plate boundaries can still have areas of higher than average natural heat flow [7].

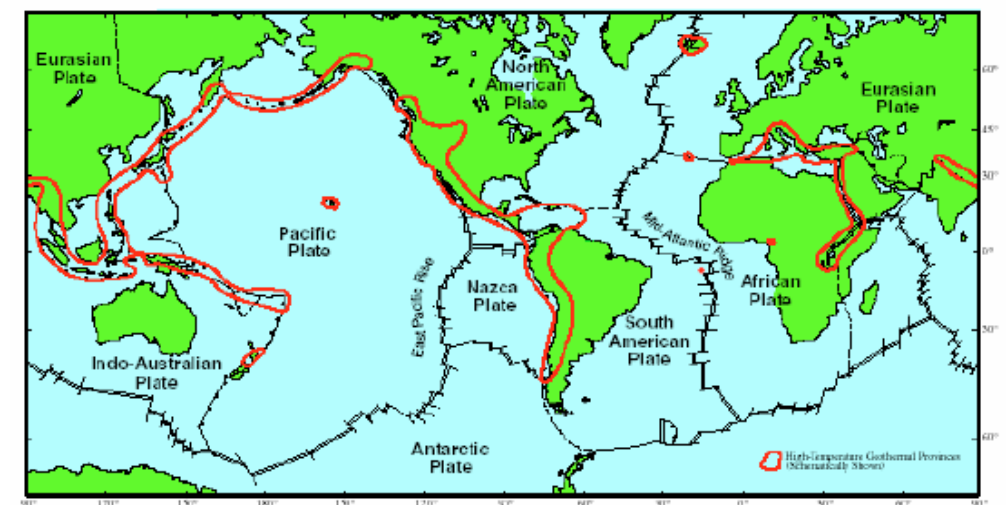

Fig. 3 Global plate tectonics ([5]) 
Most HF data are gotten from in-situ direct measurements. However, such measurements are time-consuming, low scale, cumbersome and may not be cost-effective for regional studies. Therefore, airborne observations of magnetic fields contribute to a wide range of studies: from imaging the Earth's thermal structure at all levels to modelling of geodynamic processes. The average HF in thermally continental regions is reported to be about 60 $\mathrm{mW} / \mathrm{m}^{2}$, while values in excess of about $80-100 \mathrm{~mW} / \mathrm{m}^{2}$ indicate anomalous geothermal conditions [28].

\section{GEOTHERMAL ENERGY}

Even though geothermal investigations have not received enough attention across the Nigerian landscape, very few works have been documented. The results from recent regional aeromagnetic surveys for geothermal explorations in Nigeria are shown in Table 2.

Table 2 Outcomes of recent aeromagnetic investigations for geothermal exploration in Nigeria. Only heat flow results in excess of $80 \mathrm{~mW} / \mathrm{m}^{2}$ indicating anomalous geothermal conditions are presented

\begin{tabular}{|c|c|c|c|c|c|}
\hline S/No. & Area of Study & Model Used & $\begin{array}{c}\text { Heat Flow } \\
\left(\mathrm{mW} / \mathrm{m}^{2}\right)\end{array}$ & $\begin{array}{c}\text { Nationwide } \\
\text { Survey Period }\end{array}$ & Reference \\
\hline 1 & Bida Basin & Spectral Centroid & Zones $>95$ & $\begin{array}{l}\text { High Resolution } \\
\text { of } 2004-2007\end{array}$ & [29] \\
\hline 2 & Bida Basin & Spectral Centroid & Zones $>90$ & $\begin{array}{l}\text { Low Resolution } \\
\text { of } 1970 \mathrm{~s}\end{array}$ & {$[30]$} \\
\hline 3 & Upper Bida Basin & Spectral Peak & Zones $>100$ & $\begin{array}{l}\text { Low Resolution } \\
\text { of } 1970 \mathrm{~s}\end{array}$ & {$[31]$} \\
\hline 4 & Sokoto Basin & Spectral Centroid & Zones $>110$ & $\begin{array}{l}\text { High Resolution } \\
\text { of } 2004-2009\end{array}$ & {$[32]$} \\
\hline 5 & $\begin{array}{l}\text { Upper Sokoto } \\
\text { basin }\end{array}$ & $\begin{array}{c}\text { Modified Spectral } \\
\text { Centroid }\end{array}$ & Zones $>120$ & $\begin{array}{l}\text { Low Resolution } \\
\text { of } 1970 \mathrm{~s}\end{array}$ & [27] \\
\hline 6 & Sokoto Basin & Spectral Centroid & Zones $>100$ & $\begin{array}{l}\text { Low Resolution } \\
\text { of } 1970 \mathrm{~s}\end{array}$ & [33] \\
\hline 7 & Benue Basin & Spectral Centroid & Zones $>90$ & $\begin{array}{l}\text { Low Resolution } \\
\text { of } 1970 \text { s }\end{array}$ & [34] \\
\hline 8 & Niger Delta Basin & Spectral Centroid & Zones $>80$ & $\begin{array}{l}\text { Low Resolution } \\
\text { of } 1970 \mathrm{~s}\end{array}$ & {$[34]$} \\
\hline 9 & $\begin{array}{c}\text { Ikogosi-Ekiti } \\
\text { warm spring Area }\end{array}$ & Spectral Centroid & Zones $>110$ & $\begin{array}{l}\text { Low Resolution } \\
\text { of } 1970 \mathrm{~s}\end{array}$ & {$[35]$} \\
\hline 10 & $\begin{array}{c}\text { Wikki } \\
\text { warm spring Area }\end{array}$ & Spectral Centroid & Zones $>110$ & $\begin{array}{l}\text { Low Resolution } \\
\text { of } 1970 \mathrm{~s}\end{array}$ & {$[36]$} \\
\hline
\end{tabular}

Table 2 reveals that there are regions with high heat flows in Nigeria (above $80 \mathrm{mWm}^{-2}$ ), thus suggesting anomalous geothermal conditions [28]. The geological map of Nigeria showing potential areas with estimated high heat flow values is presented in Fig. 4. Hence, strong policies to support further detailed studies are recommended for such regions. 


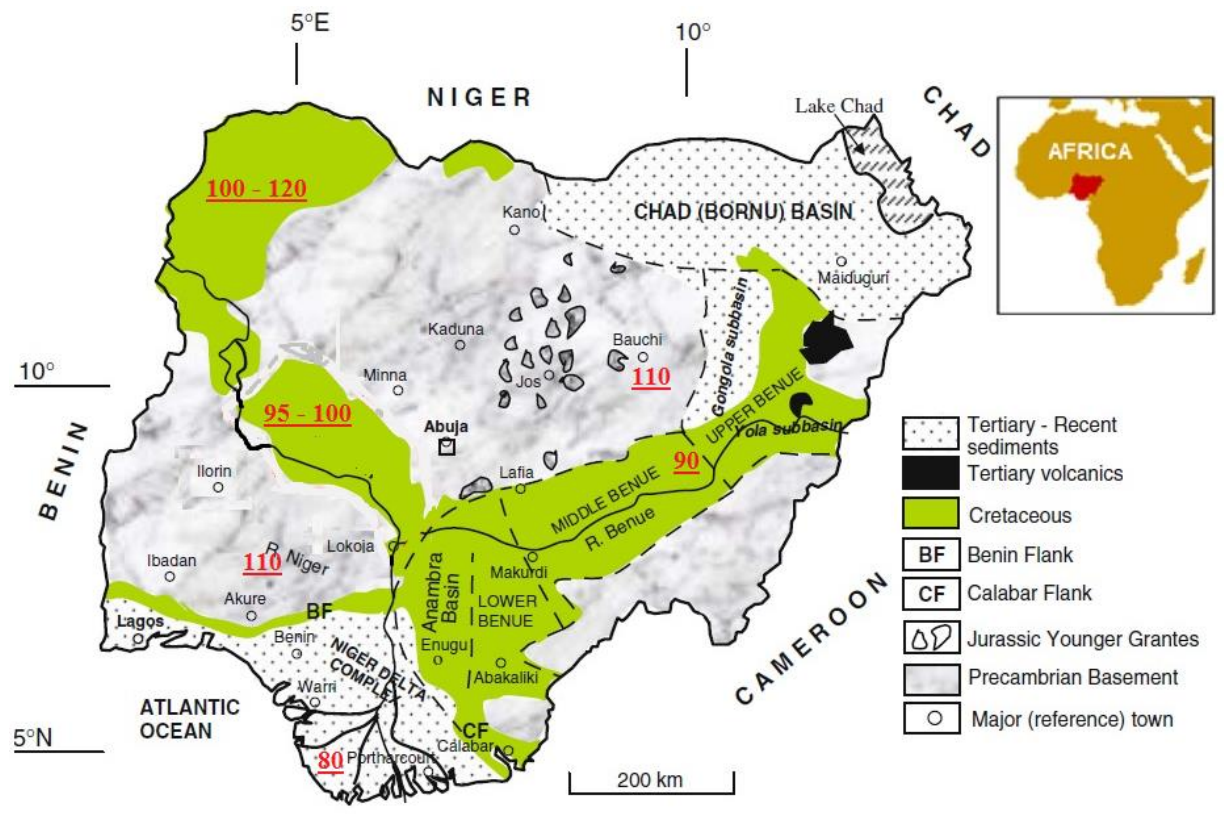

Fig. 4 Geological map of Nigeria showing elucidated areas with anomalous high heat flow in $\mathrm{mW} / \mathrm{m}^{2}$

\section{CONCLUSION}

Apart from physical evidences, anomalous high heat flow values (i.e. $80 \mathrm{~mW} / \mathrm{m}^{2}$ and above) have been observed in some parts of Nigeria. These areas could have geothermal sources and reservoirs and thereby having the capacity to contribute to national energy requirements. Therefore, these areas are recommended for further detailed geothermal exploration. Geothermal resource exploration and development is a panacea to energy crises and global warming in Nigeria. Therefore, policymakers are encouraged to support this concerted effort to diversify energy solutions in Nigeria and also take a quantum leap in holistic renewable energy development and setting concrete carbon emissions reduction goals.

Acknowledgement: The Abdus Salam International Center for Theoretical Physics (ICTP), Italy is acknowledged for the Associateship award.

\section{REFERENCES}

1. Brimmo, A. T., Sodiq, A., Sofela S. and Kolo, I., (2017), Sustainable energy development in Nigeria: Wind, hydropower, geothermal and nuclear. Renewable and Sustainable Energy Reviews. 74: $474-490$.

2. USAID (2018), Nigeria Power Africa Fact Sheet https://www.usaid.gov/powerafrica/nigeria. Accessed 1 December 2018

3. Sambo, A. S., (2015), The way forward for electricity supply in Nigeria. Ideas and Insights from Explorers, National Geographic. October 20. Assessed from www.voices.nationalgeographic.com/2015/ 10/20/the-way-forward-for-electricity-supply-in-Nigeria/ 
4. USAID (2018), South Africa Power Africa Fact Sheet https://www.usaid.gov/powerafrica/south-africa. Accessed 1 December 2018

5. IPCC (2007), Projected climate change and its impacts: Summary for policymakers. CH: IPCC.

6. Dickson, M. H. and Fanelli, M., (2004), What is geothermal energy? Instituto di geoscienze e georisorse, CNR, Pisa, Italy

7. Batini, F., (2005), Lecture note on "Geothermal Energy: Clean and Renewable Power of the Earth". Workshop on Physics for Renewable Energy. ICTP, Oct 17 - 29.

8. Session 7584, (2015), Conventional and enhanced geothermal system. AGU Fall meeting, San Francisco, 14-18 December

9. International Energy Agency. https://www.iea.org/topics/renewables/subtopics/geothermal/

10. Bertani, R., (2012), Geothermal power generation in the world 2005 - 2010 update report. Geothermics. 54: $76-81$.

11. Zemedkun, M. T., (2015), Overview of Geothermal Resource Exploration and Development. www.os.is/gogn/unu-gtp-sc/UNU-GTP-SC-17-1102.pdf

12. Babalola, O. O., (2000), High potential Geothermal Energy Resource Areas of Nigeria and their Geological and Geophysical Assessment. American Association of Petroleum Geophysicists Bulletin. 68: 231- 244.

13. Okonkwo C C, Onwuemesi A G, Anakwuba E K, Chinwuko A I, Ikumbur B E, \& Usman, A. O., (2012), Aeromagnetic interpretation over maiduguri and environs of southern Chad basin, Nigeria. Journal of earth sciences and geotechnical engineering. 2: 77-93.

14. Spector, A. and Grant, F. S., (1970), Statistical models for interpreting aeromagnetic data. Geophysics. 35: 293-302.

15. Bhattacharyya, B. K. and Leu, L. K., (1977), Spectral analysis of gravity and magnetic anomalies due to rectangular prismatic bodies. Geophysics. 42: 41-50.

16. Bhattacharyya, B. K. and Leu, L. K., (1975), Analysis of magnetic anomalies over Yellowstone National Park: mapping of Curie point isothermal surface for geothermal reconnaissance. Journal of Geophysical Research. 8: 4461-4465.

17. Okubo, Y., Graff, R. G., Hansen, R. O., Ogawa. K. and Tsu, H., (1985), Curie point depths of the Island of Kyushu and surrounding areas. Geophysics. 53: 481-494.

18. Tanaka, A. Y., Okubo, Y., and Matsubayashi, O., (1999), Curie point depth based on spectrum analysis of the magnetic anomaly data in East and Southeast Asia. Tectonophysics. 306: 461- 470.

19. Maus, S. and Dimri, V. P., (1996), Depth estimation from the scaling power spectrum of potential field. Geophys. J. Int. 124: 113-120.

20. Finn, C. A. and Ravat, D., (2004), Magnetic depth estimates and their potential for constraining crustal composition and heat flow in Antarctica. Eos. Trans. AGU 85 (47) (Fall meeting Suppl., Abstract T11A-1236).

21. Ravat, D., Pignatelli. A., Nicolosi, I. and Chiappini, M., (2007), A study of spectral methods of estimating the depth to the bottom of magnetic sources from near-surface magnetic anomaly data. Geophysical Journal International. 169: 421-434

22. Bansal, A. R., Gabriel, G., Dimri, V. P. and Krawczyk, C. M., (2011), Estimation of depth to the bottom of magnetic sources by a modified centroid method for fractal distribution of sources: An application to aeromagnetic data in Germany. Geophysics, 76(3): L11-L22.

23. Langel, R. A. and Hinze, W. J., (1998), The magnetic field of the lithosphere: the satellite perspective. U.K. Cambridge: Cambridge University Press. 429. 157-158.

24. Hsieh, H., Chen, C. and Yen, H., (2014), Curie point depth from spectral analysis of magnetic data in Taiwan. Journ. of Asian Earth Sci. 90. 26-30.

25. Stacey, F. O., (1977), Physics of the Earth, John Wiley and Sons, New York.

26. Trifonova, P., Zhelev, Z., Petrova, T. and Bojadgieva, K., (2009), Curie point depth of Bulgarian territory inferred from geomagnetic observations and its correlation with regional thermal structure and seismicity. Tectonophysics. 473: 362-374.

27. Nwankwo, L. I., (2015), Estimation of depths to the bottom of magnetic sources and ensuing geothermal parameters from aeromagnetic data of Upper Sokoto Basin, Nigeria. Geothermics. 54: 76 - 81 .

28. Jessop, A. M., Habart, M. A. and Sclater, J. G., (1976), The world heat flow data collection 1975. Geothermal Services of Canada. Geotherm Ser. 50: 55-77.

29. Nwankwo, L. I. and Sunday, A. J., (2017), Regional estimation of Curie-point depths and succeeding geothermal parameters from recently acquired high-resolution aeromagnetic data of the entire Bida basin, north-central Nigeria. Geothermal Energy Science, 5, 1-9.

30. Olorunsola, K. and Chukwu, C. G., (2018), Analysis of Geothermal Heat Flow Potentiality of Upper Bida Basin Nigeria Using Aeromagnetic Data. Appl Sci Res Rev 5:9

31. Nwankwo, L. I., Olasehinde, P. I. and Akoshile, C. O., (2011), Heat flow anomalies from the Spectral analysis of Airborne Magnetic data of Nupe Basin, Nigeria. Asian Journal of Earth Sciences. 4: 20 - 28. 
32. Nwankwo, L. I. and Shehu, A. T., (2015), Evaluation of Curie-point depths, geothermal gradients and near-surface heat flow from high-resolution aero-magnetic (HRAM) data of the entire Sokoto Basin, Nigeria. Journal of Volcanology and Geothermal Research. 305: 45-55.

33. Ofor, N. and Udensi, E. E., (2014), Determination of the Heat Flow in the Sokoto Basin, Nigeria using Spectral Analysis of Aeromagnetic Data. Journal of Natural Sciences Research, 4 (6), 83 -93

34. Adetona, A. A., Salako, K. A. and Rafiu, A. A., (2017), Curie depth and geothermal gradient from spectral analysis of aeromagnetic data over Upper Anambra and Lower Benue Basin, Nigeria. Nigerian Journal of Technological Research, 12(2)

35. Abraham, E. M., Lawal, K. M., Ekwe, A. C., Alile, O., Murana, K. A., and Lawal, A. A., (2014), Spectral analysis of aeromagnetic data for geothermal energy investigation of Ikogosi Warm Spring - Ekiti State, southwestern Nigeria. Geothermal Energy. 2: 6 - 10

36. Obande, G. E., Lawal, K. M. \& Ahmed, L. A., (2014), Spectral analysis of aeromagnetic data for geothermal investigation of Wikki warm Spring, north-east Nigeria. Geothermics 50, 11 - 90.

\section{POTENCIJAL GEOTERMALNE ENERGIJE NA OSNOVU AEROMAGNETSKIH ISPITIVANJA: JOŠ JEDNO REŠENJE ZA ENERGETSKE KRIZE I GLOBALNO ZAGREVANJE U NIGERIJI}

U radu je prikazan pokušaj zalaganja za pronalaženje rešenja za sve dominantniju energetsku krizu u Nigeriji, kroz sagledavanje potencijala geotermalnih energetskih resursa u zemlji dobijenih na osnovu regionalnih aeromagnetskih merenja. U Nigeriji postoji veliki broj termalnih izvora, čime se potvrđuju dostupnost $i$ velike količine geotermalnih rezervi. Rezultati aeromagnetnih istraživanja takođe potvrđuju da u Nigeriji postoje područja sa izuzetno velikim protokom toplote, što predstavlja veliku mogućnost za direktnu i indirektnu upotrebu geotermalne energije. Nigerija mora da napravi , kvantni skok" $u$ holističkim istraživanjima i u razvoju obnovljivih izvora energije kroz saradnju sa naučnicima i ministarstvima, oslanjajući se na politiku i pricipe upravljanja životnom sredinom.

Ključne reči: geotermalna energija, obnovljivi izvori energije, politika zaštite životne sredine, termalni izvori, Nigerija 